\title{
Analysis of Clinical Characteristics and Diagnostic Value of Fungal Serology in Patients with Invasive Candidiasis
}

\author{
Heqiu Ruan*, Weihua Xu*, Mengjuan Xia, Zhichao Ma, Shengmiao Fu, Xinping Chen\# \\ Central Laboratory, Hainan General Hospital, Hainan Hospital Affiliated to The Hainan Medical College, Hainan Provincial Key \\ Laboratory of Cell and Molecular Genetic Translational Medicine, Haikou, China \\ Email: "chenxinping52@126.com
}

How to cite this paper: Ruan, H.Q., Xu, W.H., Xia, M.J., Ma, Z.C., Fu, S.M. and Chen, X.P. (2020) Analysis of Clinical Characteristics and Diagnostic Value of Fungal Serology in Patients with Invasive Candidiasis. Open Journal of Medical Microbiology, 10, 222-232.

https://doi.org/10.4236/ojmm.2020.104019

Received: November 28, 2020

Accepted: December 26, 2020

Published: December 29, 2020

Copyright $\odot 2020$ by author(s) and Scientific Research Publishing Inc. This work is licensed under the Creative Commons Attribution International License (CC BY 4.0).

http://creativecommons.org/licenses/by/4.0/

\begin{abstract}
Objective: To evaluate the diagnostic value of ( 1 - 3)- $\beta$-D glucan and mannan assay for invasive candidiasis. Methods: A retrospective study was conducted on 32 cases in the disease group (18 proven invasive candidiasis and 14 probable invasive candidiasis) and 48 cases in the control group. The subjects were recruited from January 2018 to March 2019 in Clinical Laboratory of Hainan General Hospital. All subjects were detected by (1 - 3)- $\beta$-D glucan and mannan assay. Results: The mean concentration of $(1-3)-\beta$-D glucan in the disease group was $97.45(43.23,224.35) \mathrm{pg} / \mathrm{ml}$ and it was significantly higher than the mean concentration of the control group which was $49.85(41.91,56.07) \mathrm{pg} / \mathrm{ml}(P=0.005)$. The mean concentration of mannan in the disease group and the control group were $161.36(34.96,224.49) \mathrm{pg} / \mathrm{ml}$ and $25.80(25.00,29.31) \mathrm{pg} / \mathrm{ml}$, respectively, which were significantly different $(P<0.001)$. The sensitivity, specificity, positive predictive value and negative predictive value of $(1-3)-\beta$-D glucan assay were $59.38 \%, 89.58 \%, 79.17 \%$, $76.79 \%$, respectively. The sensitivity, specificity, positive predictive value and negative predictive value of mannan assay were $65.63 \%, 95.83 \%, 91.30 \%$, $80.70 \%$, respectively. The sensitivity, specificity, positive predictive value and negative predictive value of combination of two types of assays were $81.25 \%$, $85.42 \%, 78.79 \%$ and $87.23 \%$, respectively. Conclusions: Combination of (1 3 )- $\beta$-D glucan and mannan assay can improve diagnostic specificity and it has essential clinical diagnostic value for invasive candidiasis.
\end{abstract}

\section{Keywords}

Invasive Candidiasis, Mannan, (1 - 3)- $\beta$-D Glucan, Combination of Serological Tests

*These authors contribute equally to this work; ${ }^{\sharp}$ Corresponding author. 


\section{Introduction}

Invasive candidiasis usually occurs in immunocompromised patients, with a prevalence of $2.1-21 / 100,000$ and a fatality rate of $40 \%-60 \%$. Total parenteral nutrition, indwelling central venous catheter (CVC), giving antibiotics and glucocorticoids as well as abdomen surgery are all high risk factors for candidiasis [1]. The usage of antibiotics destroys the balance of gut microbiome, leading to growth advantages of Candida. Gastrointestinal surgery or perforation and/or CVC damage the intestinal barrier. Candida albicans colonized in the intestinal cavity breaks through the intestinal mucosal barrier and invades into the blood, causing Candidaemia and invasive candidiasis. Moreover, neutropenia caused by chemotherapy or corticosteroid treatment undermines the natural immune defense and leads to Candida invasion [2] [3].

It is conducive to the early diagnosis of fungi through identifying and preventing high-risk factors of complicating with fungal infection. Culture and tissue biopsy are evidence of fungal infection. However, detection time of fungus culture is long and positive rate is low. Histopathology is inconvenient for critically ill patients due to invasive procedures [4]. In recent years, serological testing attracted more clinical attention.

(1 - 3)- $\beta$-D glucan exists in fungal cell wall [5], using as a detection marker for a variety of pathogenic fungal infections. $(1-3)$ - $\beta$-D-glucan is a highly immunogenic molecule with a specific pattern recognition receptor dectin-1 on the surface of host immune cells. Dectin-1 can mediate phagocytosis, cytokine and chemokine production, leading to a strong immunological response [6]. Mannan is a glycoprotein exposed on the outermost layer of the cell wall and it may be the first molecule to interact with host dendritic cell. Mannan promotes the maturation and activation of dendritic cell, completes the antigen presentation, and activates immune response. Different structures of mannans bind to different types of receptors for dendritic cells: $\alpha$-mannan of Candida albicans bind to dectin- 2 receptor, while $\beta$-mannan recognized by galectin- 3 and Toll-like receptor 2 (TLR-2) [7] [8]. Jiang et al. demonstrate that compared with the bacterial infection group, the Candida colonization group and the control group, the positive rate of mannan group was significantly higher in the invasive candidiasis [9]. When mannan detection using enzyme-linked immunoassay technology, it can improve the diagnostic performance of invasive fungal diseases [10]. This study explored the clinical diagnostic value of combined detection of ( 1 - 3)- $\beta$-D glucan and Candida mannan in invasive candidiasis through a retrospective study.

\section{Materials and Method}

Study participants: Participants consisted of the disease group (32 cases of invasive candidiasis, including 18 proven cases and 14 probable cases) and 48 cases of the control group (patients under physical examination) collected from the Clinical Laboratory of Hainan General Hospital from January 2018 to March 
2019. The enrolled patients all met the diagnostic criteria in the 2019 EORTC/MSG guideline [11]. The study was approved by the Ethics Committee of Hainan General Hospital.

Instruments and reagents: Fungus ( 1 - 3)- $\beta$-D-Glucan, Candida Mannan Assay (ELISA) provided by Dynamiker Biotechnology (Tianjin) Co., Ltd, enzyme-labeled instrument (SUNRISE, TECAN).

Method: $5 \mathrm{~mL}$ venous blood centrifuged at $3000 \mathrm{rpm}$ for $10-15$ minutes and collected the supernatant. If the test was completed within 24 hours, it could be stored at $4^{\circ} \mathrm{C}$, otherwise it could be stored at $-20^{\circ} \mathrm{C}$ to avoid repeated freezing and thawing. Serum samples were tested with Fungus $(1-3)-\beta$-D-Glucan (G test) and Candida Mannan Assay (Mn test), the results were fetched by enzyme-labeled instrument. Thresholds of G test and $\mathrm{Mn}$ test were $70 \mathrm{pg} / \mathrm{ml}$ and $50 \mathrm{pg} / \mathrm{ml}$, respectively.

Statistical analysis: Mann-Whitney U test was performed using IBM SPSS Statistics 21.0 software to complete concentration level analysis and differences were considered significant at $P<0.05$. GraphPad Prism 5 was applied to drawing graph of concentration level. Receiver operating characteristic curve (ROC) was established by IBM SPSS Statistics 21.0 software and the area under the curve (AUC) was a $95 \%$ confidence interval. $P<0.05$ indicated statistical significance.

\section{Result}

1) Patient characteristics: The results showed that the median age of the disease group was $68.00(58.50,76.75)$ and the median age of the control group was $36.00(31.00,52.00)$. The difference between the two groups was statistically significant $(\mathrm{Z}=6.058, P<0.001)$. The underlying disease, imaging characteristics, microbial culture results, antifungal treatment and treatment outcome of $32 \mathrm{pa}-$ tients in the disease group were shown in Table 1. The common underlying disease was pulmonary infection (pneumonia) (31 cases, 96.88\%), followed by MODs (9 cases, 28.13\%), respiratory failure (8 cases, 25.00\%), sepsis/septic shock/pyemia (6 cases, $18.75 \%$ ) and cancer/tumor (6 cases, $18.75 \%)$. The imaging features statistics were as follows: cavity ( 2 cases, $6.25 \%)$, exudative lesion ( 9 cases, 28.13\%), pulmonary bulla (2 cases, 6.25\%), miliary shadow (1 case, $3.13 \%)$, nodule ( 2 cases, $6.25 \%$ ), patchy ( 1 case, $3.13 \%)$, stripe shadow ( 1 case, $3.13 \%)$, emphysema (1 case, $3.13 \%$ ) and air containing space (1 case, $3.13 \%$ ), Table 1.

2) Concentration levels of $\mathrm{G}$ test and $\mathrm{Mn}$ test in disease group and control group: The median concentration of $\mathrm{G}$ test in the disease group was 97.45 $(43.23,224.35) \mathrm{pg} / \mathrm{ml}$, which was significantly higher than $49.85(41.91,56.07)$ $\mathrm{pg} / \mathrm{ml}(\mathrm{Z}=-2.809, P=0.005)$ in the control group. The median concentration of Mn test of patients in the disease group was $161.36(34.96,224.49) \mathrm{pg} / \mathrm{ml}$ and compared with $25.80(25.00,29.31) \mathrm{pg} / \mathrm{ml}$ in the control group, it was significant difference $(\mathrm{Z}=-5.547, P<0.001)$ (Figure 1$)$. 
Table 1. Characteristics of patients.

\begin{tabular}{|c|c|c|c|c|c|c|}
\hline $\begin{array}{c}\text { Serial } \\
\text { number }\end{array}$ & $\begin{array}{l}\text { Diagnostics } \\
\text { result }\end{array}$ & Underlying disease & Image feature & Culture & Antifungal treatment & $\begin{array}{l}\text { Treatment } \\
\text { outcome }\end{array}$ \\
\hline 1 & Proven & $\begin{array}{c}\text { Sepsis, } \\
\text { septic shock, MODs, } \\
\text { Severe pneumonia }\end{array}$ & None & $\begin{array}{l}\text { Candida albicans } \\
\text { by blood culture }\end{array}$ & Meropenem + voriconazole & Death \\
\hline 2 & Proven & $\begin{array}{l}\text { Hospital } \\
\text { acquired } \\
\text { pneumonia }\end{array}$ & $\begin{array}{l}\text { Bilateral Lung } \\
\text { exudative lesion }\end{array}$ & $\begin{array}{l}\text { Candida albicans } \\
\text { by blood culture }\end{array}$ & $\begin{array}{l}\text { Fluconazole }+ \text { linezolid }+ \\
\text { Meropenem }\end{array}$ & Discharged \\
\hline 3 & Proven & $\begin{array}{l}\text { Left middle cerebral } \\
\text { artery aneurysm, right } \\
\text { vertebral artery } \\
\text { dissecting aneurysm, } \\
\text { pulmonary infection }\end{array}$ & $\begin{array}{l}\text { Exudative lesion } \\
\text { of inferior lobe of } \\
\text { Bilateral Lung }\end{array}$ & $\begin{array}{l}\text { Candida tropicalis } \\
\text { and Candida albicans } \\
\text { by blood culture }\end{array}$ & Cefoperazone/Sulbactam & Discharged \\
\hline 4 & Proven & $\begin{array}{l}\text { Aspiration pneumonia, } \\
\text { type II respiratory failure }\end{array}$ & $\begin{array}{l}\text { Bilateral Lung } \\
\text { exudative lesion }\end{array}$ & $\begin{array}{l}\text { Candida tropicalis } \\
\text { by blood culture }\end{array}$ & $\begin{array}{l}\text { Caspofungin + Piperacillin } \\
\text { Sodium and Sulbactam } \\
\text { Sodium + Levofloxacin Lactate }\end{array}$ & Discharged \\
\hline 5 & Proven & $\begin{array}{l}\text { Pulmonary infection, } \\
\text { right lung carcinoma }\end{array}$ & None & $\begin{array}{l}\text { Candida albicans and } \\
\text { Candida dubliniens } \\
\text { by blood culture }\end{array}$ & Caspofungin & $\begin{array}{c}\text { Was } \\
\text { critically } \\
\text { ill }\end{array}$ \\
\hline 6 & Proven & Pulmonary infection & None & $\begin{array}{l}\text { Candida albicans } \\
\text { by blood culture }\end{array}$ & Meropenem + Levofloxacin & Discharged \\
\hline 7 & Proven & $\begin{array}{l}\text { Type II respiratory } \\
\text { failure, pulmonary } \\
\text { infection }\end{array}$ & $\begin{array}{l}\text { Lesser tubercle of } \\
\text { superior segment } \\
\text { of inferior lobe } \\
\text { of right lung, } \\
\text { emphysema and } \\
\text { pulmonary bullae } \\
\text { of bilateral Lung }\end{array}$ & $\begin{array}{l}\text { Candida albicans } \\
\text { by blood culture }\end{array}$ & $\begin{array}{l}\text { Meropenem + Etimicin }+ \\
\text { Cefopergone Tazobactam }\end{array}$ & $\begin{array}{c}\text { Was } \\
\text { consciousness } \\
\text { disorder and } \\
\text { discharged }\end{array}$ \\
\hline 8 & Proven & Pulmonary infection & $\begin{array}{l}\text { Bilateral Lung } \\
\text { exudative lesion, } \\
\text { cavitation of } \\
\text { superior lobe of } \\
\text { right lung }\end{array}$ & $\begin{array}{l}\text { Candida parapsilosis } \\
\text { by blood culture }\end{array}$ & Caspofungin & Discharged \\
\hline 9 & Proven & $\begin{array}{l}\text { MODs, pyemia, } \\
\text { septic shock, } \\
\text { Pulmonary infection }\end{array}$ & None & $\begin{array}{l}\text { Candida albicans } \\
\text { by blood culture }\end{array}$ & $\begin{array}{l}\text { Piperacillin Sodium and } \\
\text { Sulbactam Sodium }\end{array}$ & Discharged \\
\hline 10 & Proven & Pulmonary infection & None & $\begin{array}{l}\text { Candida tropicalis } \\
\text { by blood culture }\end{array}$ & None & l \\
\hline 11 & Proven & Bacterial pneumonia & $\begin{array}{l}\text { Air containing } \\
\text { space of superior } \\
\text { lobe of right lung }\end{array}$ & $\begin{array}{l}\text { Candida albicans } \\
\text { by blood culture }\end{array}$ & $\begin{array}{l}\text { Cefoperagone Sodium and } \\
\text { Tazobactam Sodium }+ \\
\text { imipenem-cilas-tatin }\end{array}$ & l \\
\hline 12 & Proven & $\begin{array}{l}\text { MODs, pyemia, } \\
\text { Pulmonary infection }\end{array}$ & None & $\begin{array}{l}\text { Candida albicans } \\
\text { by blood culture }\end{array}$ & Doxycycline + fluconazole & Death \\
\hline 13 & Proven & $\begin{array}{c}\text { Pyemia, septic shock, } \\
\text { Severe pneumonia, MODs }\end{array}$ & None & $\begin{array}{l}\text { Candida glabrata } \\
\text { by blood }\end{array}$ & l & I \\
\hline 14 & Proven & $\begin{array}{l}\text { Respiratory failure, } \\
\text { Pulmonary infection }\end{array}$ & None & $\begin{array}{l}\text { Candida lusitaniae } \\
\text { by blood }\end{array}$ & l & I \\
\hline 15 & Proven & Pulmonary infection & None & $\begin{array}{l}\text { Candida tropicalis } \\
\text { by blood }\end{array}$ & l & I \\
\hline
\end{tabular}




\section{Continued}

16

Proven

None

None

Emphysema of superior lobe of

Bilateral Lung, nodule of anterior segment of superior lobe of left lung

18 Proven

19\# Probable after radiotherapy and chemotherapy,

Type I respiratory failure

\section{Pulmonary}

adenocarcinoma,

Pulmonary infection, Type II respiratory failure

22 Probable

Pulmonary infection

Bacterial pneumonia

Probable

Aspiration pneumonia,

Type I respiratory failure

Pulmonary infection, Type I respiratory failure

26

Probable

Pulmonary infection

MODs, septic shock, Pulmonary infection

MODs,

Severe pneumonia
Bilateral Lung exudative lesion

Candida albicans by sputum smear

Bilateral Lung patchy shadow

Bilateral Lung exudative lesion

Bilateral lung lesions with enlarged cavities

Exudative lesion of inferior lobe of left lung

None

None

None

Bilateral lung diffuse miliary shadow

Candida albicans by sputum smear

Candida albicans by sputum smear

Candida albicans by sputum smear

Candida albicans by sputum smear

Candida albicans by sputum smear

Candida albicans by sputum smear

Candida albicans by sputum smear

Candida albicans by sputum smear
Candida albicans

by blood culture

Candida albicans by blood culture

Candida albicans by blood culture

Candida albicans by sputum smear None Discharged

Piperacillin Sodium and Sulbactam Sodium

Discharged

Piperacillin Sodium and Sulbactam Sodium

Was critically ill and discharged
Fluconazole + Caspofungin

Discharged

Using Cefoperagone Sodium and Tazobactam Sodium + fluconazole to fight infection, but ineffective, instead of imipenem

Piperacillin Sodium and Sulbactam Sodium

Was critically ill and discharged

Was Sulbactam Sodium uncontrolled infection and discharged

Cefoperagone Sodium and Tazobactam Sodium

Discharge

Was

Meropenem + voriconazole + respiratory Cefoperazone/Sulbactam + fluconazole
Piperacillin Sodium and discharged 


\section{Continued}

\begin{tabular}{|c|c|c|c|c|c|c|}
\hline 29 & Probable & $\begin{array}{c}\text { Pyemia, septic shock, } \\
\text { MODs, } \\
\text { Severe pneumonia }\end{array}$ & $\begin{array}{l}\text { Nodule, patchy and } \\
\text { stripe shadow of } \\
\text { bilateral Lung }\end{array}$ & $\begin{array}{l}\text { Candida albicans } \\
\text { by sputum smear }\end{array}$ & I & l \\
\hline 30 & Probable & Pulmonary infection & $\begin{array}{l}\text { Exudative lesion of } \\
\text { inferior lobe of } \\
\text { Bilateral Lung }\end{array}$ & $\begin{array}{l}\text { Candida albicans } \\
\text { by sputum smear }\end{array}$ & I & l \\
\hline 31 & Probable & $\begin{array}{l}\text { Acute interstitial } \\
\text { pneumonia, Severe } \\
\text { pneumonia, MODs }\end{array}$ & None & $\begin{array}{l}\text { Candida albicans } \\
\text { by sputum smear }\end{array}$ & I & I \\
\hline 32 & Probable & $\begin{array}{l}\text { Pulmonary } \\
\text { infection }\end{array}$ & None & $\begin{array}{l}\text { Candida albicans } \\
\text { by sputum smear }\end{array}$ & I & I \\
\hline
\end{tabular}

${ }^{\Phi}$ MODs, Multiple organ dysfunction syndrome; \#, This patient carried out pulmonary tumor resection and lymphadenectomy over 14 months ago in other hospital; /, Situation unknown; +, Combined application.
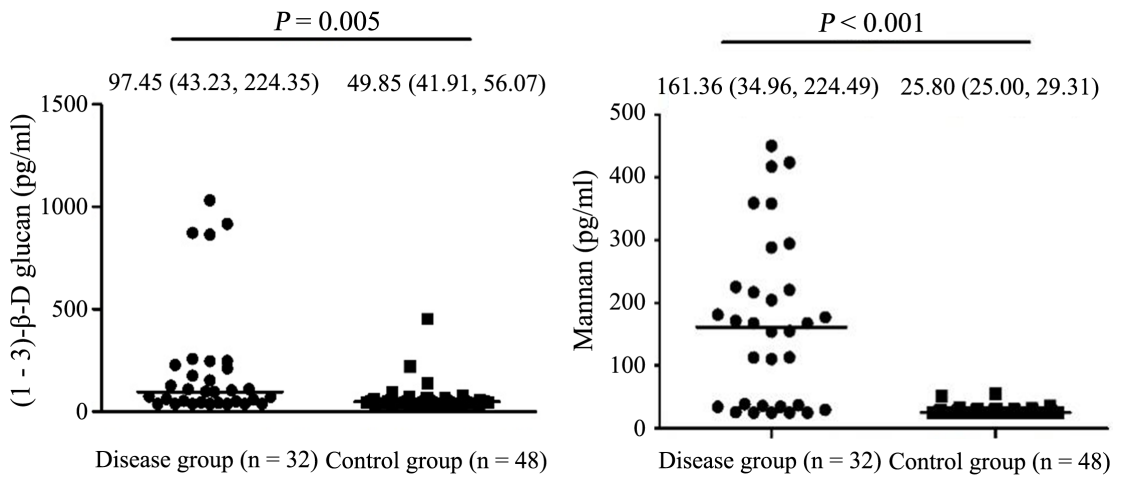

Figure 1. Comparison of concentration levels of $\mathrm{G}$ test and $\mathrm{Mn}$ test in the disease group and the control group.

3) Diagnostic performance of $\mathrm{G}$ test, $\mathrm{Mn}$ test and combined detection: The sensitivity, specificity, positive predictive value (PPV) and negative predictive value (NPV) of the G test were $59.38 \%, 89.58 \%, 79.17 \%$, and $76.79 \%$, respectively. The above values of $\mathrm{Mn}$ test were $65.63 \%, 95.83 \%, 91.30 \%, 80.70 \%$ respectively. The sensitivity, specificity, PPV and NPV of the combined detection of two tests were $81.25 \%, 85.42 \%, 78.79 \%$, and $87.23 \%$, respectively (Table 2).

4) ROC of G test and Mn test: The AUC of G test and Mn test in the diagnosis of invasive Candida were 0.686 and 0.865 , respectively. The optimal cut off of G test was $72.17 \mathrm{pg} / \mathrm{ml}$, corresponding, the sensitivity and specificity were $59.40 \%$ and $89.60 \%$. The optimal cut off of $\mathrm{Mn}$ test was $34.09 \mathrm{pg} / \mathrm{ml}$, the sensitivity and specificity were $81.3 \%$ and $93.7 \%$ (Figure 2).

5) Classification of species of candida: Among 32 cases in disease group, $81.25 \%$ of patients were infected with Candida albicans, which was the main pathogen. Non-Albicans infections were as follows: four cases of Candida tropicalis (12.50\%), 1 case of Candida glabrata (3.13\%), 1 case of Candida parapsilosis (3.13\%), 1 case of Candida dubliniensis (3.13\%) and 1 case of Candida lusitaniae (3.13\%). 


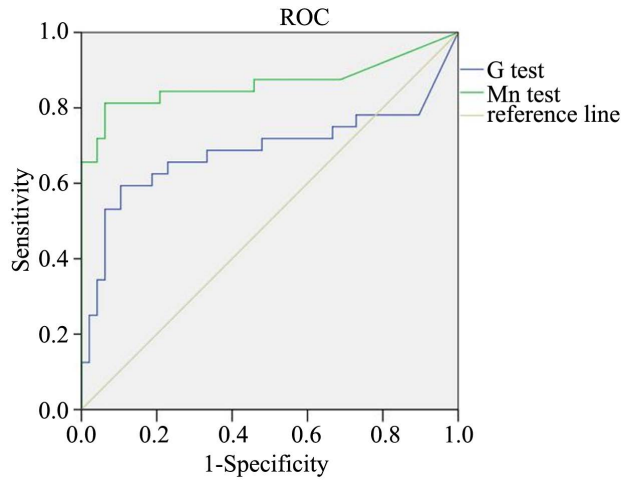

Figure 2. ROC of invasive candidiasis by G test and Mn test.

Table 2. Diagnostic value of G test and Mn test.

\begin{tabular}{ccccc}
\hline & Sensitivity (\%) & Specificity (\%) & PPV (\%) & NPV (\%) \\
\hline G test & $59.38 \%$ & $89.58 \%$ & $79.17 \%$ & $76.79 \%$ \\
Mn test & $65.63 \%$ & $95.83 \%$ & $91.30 \%$ & $80.70 \%$ \\
G/Mn test & $81.25 \%$ & $85.42 \%$ & $78.79 \%$ & $87.23 \%$ \\
\hline
\end{tabular}

I, if one of the two detection methods was positive, the result was judged as positive, otherwise it was negative.

\section{Discussion}

The results of this study showed that the median age of the disease group was $68.00(58.50,76.75)$ and the median age of the control group was 36.00 (31.00, 52.00). Our results indicated that elderly patients may be prone to invasive Candidiasis. It is previously reported that Candida is the most common type of fungus infection in elderly patients [12], with an incidence rate of $45.3 \%$, which may be related to reduced immune function in the elderly [13]. In addition, 28 patients in the disease group gave details of their ward types, showing that patients were mainly concentrated in the emergency intensive care unit and the respiratory and critical care unit $(75.00 \%, 21 / 28)$, which was consistent with the report [14]. At the same time, most patients with Candida infection had lung infections (96.85\%, 31/32), of which 8 patients $(25.00 \%, 8 / 32)$ had respiratory failure. The underlying factors of Candida infection are related to the dysbiosis caused by broad-spectrum antibiotic treatment, mechanical ventilation and tracheal intubation [15] and other respiratory support interventions.

Clinical indicators such as C-reactive protein (CRP) and white blood cell count $(\mathrm{WBC})$ can be used to determine the presence of infectious diseases and the types of pathogens. In this study, 32 patients in the disease group had elevated CRP (25 cases, 78.13\%), elevated WBC (19 cases, 59.38\%), and elevated neutrophils (21 cases, 65.63\%). The increase in CRP and WBC is closely related to various types of infections. For example, CRP has an increasing trend in fungal and bacterial infections [16] [17]. Therefore, when clinical presentations of both are high and bacterial cultures are negative, deep fungal infections, including Candida [18], should be considered. Another result of this study showed that 
most patients with Candida infection had elevated neutrophils, which was consistent with the results of Liu Haibo et al. [19].

In this study, the median concentrations of $\mathrm{G}$ test and Mn test of the disease group were significantly higher than those of the control group, and the difference was statistically significant, confirming that G test and Mn test have clinical diagnostic significance for invasive candidiasis. Among 18 patients in the proven group, 16 patients were divided into Candida albicans group and non-albicans Candida (NAC) group (exclude 2 patients with both Candida albicans and NAC infection). The median concentrations of $\mathrm{G}$ test in the Candida albicans group and the NAC group were $118.35(86.95,220.60) \mathrm{pg} / \mathrm{mL}$ and $75.85(37.50,912.53)$ $\mathrm{pg} / \mathrm{mL}$, respectively, and the difference was not statistically significant $(\mathrm{Z}=$ $-0.544, P=0.586)$. At the same time, the median concentration of $\mathrm{Mn}$ test in Candida albicans group and NAC group was $163.15(28.52,207.93) \mathrm{pg} / \mathrm{mL}$ and $196.97(32.27,419.21) \mathrm{pg} / \mathrm{mL}$, and there was no statistical difference between the groups $(Z=-0.868, P=0.385)$. These results indicated that the two detection methods were not interfered by the species of Candida, which was consistent with the report by Vindana Chibabhai et al. [20]. A study enrolling 188 patients with Candida infection shows that the majority of cases are Candida albicans infection, up to 93 cases (49.50\%) [21]. Similarly, the proportion of patients with Candida albicans infection was relatively large $(81.25 \%)$ in this study. Nevertheless, the number of cases of NAC infection has been on the rise in recent years [22] [23]. In this study, we also noticed NAC infections, such as Candida glabrata, Candida tropicalis, etc.

Among the 32 patients with invasive candidiasis, 11 patients had negative serum mannan tests. This may be because mannan activates the body's immune cells, resulting in the formation of antigen-antibody complexes, which reduces the blood concentration of mannan below the minimum detection limit; or the low concentration of Candida invading the human blood system makes the test false Negative. It has been reported that only $31 \%$ to $90 \%$ of patients with candidemia will have high concentrations of mannan, which may be related to the rapid clearance or degradation of mannan in the blood [9] [24]. Among the 32 cases of invasive candidiasis, 13 had a negative serum $G$ test. It may be because ( 1 - 3)- $\beta$-D glucan is not distributed on the surface of the fungus. The glucan can only be released after being phagocytosed by phagocytes. In the early stage of infection, the $\mathrm{G}$ test detects the substance 1,3- $\beta$-D-glucan which has not reached a positive level; it is also possible that patients with neutrophil deficiency and neutrophil phagocytic dysfunction cannot release $1,3-\beta$-D-glucan from fungi. These will cause false negatives in the G test [25] [26].

In summary, the $\mathrm{G}$ test and the Mn test have certain value in the clinical diagnosis of invasive candidiasis. The combined detection of the pan-fungal $G$ test and the specific Mn test can improve the sensitivity and specificity of detection [27]. The study shows that the $G$ test was positive 5 days earlier than the first fever, 10.7 days earlier than respiratory symptoms, and 9.3 days earlier than lung imaging changes. The Mn test report results 4 days earlier than blood culture 
which results in candidaemia [20] [26]. It is reported that a negative G test can stop the empirical antifungal treatment of patients with high risk of invasive candidiasis in the ICU [28] [29]. Therefore, it is best to use a combination of fungal culture and serological testing in clinical diagnosis to make up for the shortcomings of traditional testing methods.

\section{Conflicts of Interest}

The authors declare no conflicts of interest regarding the publication of this paper.

\section{References}

[1] Chinese Adult Candidiasis Diagnosis and Management Expert Consensus Group (2020) Chinese Consensus on the Diagnosis and Management of Adult Candidiasis. Chinese Journal of Internal Medicine, 59, 5-17. https://doi.org/10.3760/cma.j.issn.0578-1426.2020.01.002

[2] Pappas, P.G., Lionakis, M.S. Arendrup, M.C., Ostrosky-Zeichner, L. and Kullberg, B.J. (2018) Invasive Candidiasis. Nature Reviews Disease Primers, 4, Article No. 18026. https://doi.org/10.1038/nrdp.2018.26

[3] Tong, Y. and Tang, J. (2017) Candida albicans Infection and Intestinal Immunity. Microbiological Research, 198, 27-35. https://doi.org/10.1016/j.micres.2017.02.002

[4] Li, H., Fang, W.J., Xiong, L., et al. (2019) Research Progress on Early Diagnosis of Invasive Fungal Infection. Mycological Society of China, 38, 151-158.

[5] Garcia-Rubio, R., de Oliveira, H.C., Rivera, J., et al. (2019) The Fungal Cell Wall: Candida, Cryptococcus, and Aspergillus Species. Frontiers in Microbiology, 10, 2993. https://doi.org/10.3389/fmicb.2019.02993

[6] Hernández-Chávez, M.J. and Pérez-García, L.A. (2017) Fungal Strategies to Evade the Host Immune Recognition. Journal of Fungi, 3, 51. https://doi.org/10.3390/jof3040051

[7] Paulovičová, L., Paulovičová, E., Farkaš, P., et al. (2019) Bioimmunological Activities of Candida glabrata Cellular Mannan FEMS Yeast Research, 19, foz009. https://doi.org/10.1093/femsyr/foz009

[8] Nguyen, T.N.Y., Matangkasombut, O. and Ritprajak, P. (2018) Differential Dendritic Cell Responses to Cell Wall Mannan of Candida albicans, Candida parapsilosis, and Candida dubliniensi. Journal of Oral Science, 60, 557-566. https://doi.org/10.2334/josnusd.17-0426

[9] Jiang, Y.T., Xiao, Q.W., Su, D.H., et al. (2016) The Determination of Mannan for the Diagnosis of Invasive Candidiasis. Laboratory Medicine, 31, 603-606.

[10] Huang, T.F. and Zhu, Y.M. (2016) Research Progress on the Early Diagnosis of Invasive Candida Infection: An Up-to-Date Review. Chinese Pediatric Emergency Medicine, 23,117-120. https://doi.org/10.1111/acem.12774

[11] Donnelly, J.P., Chen, S.C., Kauffman, C.A., et al. (2019) Revision and Update of the Consensus Definitions of Invasive Fungal Disease From the European Organization for Research and Treatment of Cancer and the Mycoses Study Group Education and Research Consortium. Clinical Infectious Diseases, 71, 1367-1376. https://doi.org/10.1093/cid/ciz1008

[12] Gong, Y., Li, C., Wang, C., et al. (2020) Epidemiology and Mortality-Associated Factors of Invasive Fungal Disease in Elderly Patients: A 20-Year Retrospective Study from 
Southern China. Infection and Drug Resistance, 13, 711-723. https://doi.org/10.2147/IDR.S242187

[13] Hof, H. (2010) Mycoses in the Elderly. European Journal of Clinical Microbiology and Infectious Diseases, 29, 5-13. https://doi.org/10.1007/s10096-009-0822-5

[14] Song, X.P. and Zheng, R. (2019) Progress in Diagnosis and Treatment of Candida Bloodstream Infection. Medical Recapitulate, 25, 758-762.

[15] Lai, C.C., Tsai, H.Y., Chang, T.C., et al. (2013) Catheter-Related Fungemia Caused by Candida dubliniensis. Journal of Microbiology Immunology and Infection, 46, 306-308. https://doi.org/10.1016/j.jmii.2012.10.001

[16] Guo, J., Wu, Y., Lai, W., et al. (2019) The Diagnostic Value of (1,3)- $\beta$-D-Glucan Alone or Combined with traditional Inflammatory Markers in Neonatal Invasive Candidiasis. BMC Infectious Diseases, 19, Article No. 716. https://doi.org/10.1186/s12879-019-4364-X

[17] Stoma, I., Karpov, I., Uss, A., et al. (2019) Combination of Sepsis Biomarkers may Indicate an Invasive Fungal Infection in Haematological Patients. Biomarkers, 24, 401-406. https://doi.org/10.1080/1354750X.2019.1600023

[18] Shi, Y.Z., Zhang, J. and Xie, X.Y. (2016) Correlation between White Blood Cell Count, C-Reactive Protein Detection and Deep Candida Infection in Dying Elderly Patient. Chinese Journal of Gerontology, 36, 5122-5123.

[19] Liu, H.B., Wei, D., Xia, J.H., et al. (2017) Clinical Epidemiology and Prognositic Analysis of Nosocomial Candidemia. Chinese Journal of Infection and Chemotherapy, 17, 492-497.

[20] Chibabhai, V., Fadana, V., Bosman, N. and Nana, T. (2019) Comparative Sensitivity of 1,3beta-D-Glucan for Common Causes of Candidaemia in South Africa. Mycoses, 62, 1023-1028. https://doi.org/10.1111/myc.12982

[21] Wang, K., Luo, Y., Zhang, W., et al. (2020) Diagnostic Value of Candida Mannan Antigen and Anti-Mannan IgG and IgM Antibodies for Candida Infection. Mycoses, 63, 181-188. https://doi.org/10.1111/myc.13035

[22] Fu, J., Ding, Y., Wei, B., et al. (2017) Epidemiology of Candida albicans and Non-C. albicans of Neonatal Candidemia at a tertiary Care Hospital in Western China. BMC Infectious Diseases, 17, Article No. 329. https://doi.org/10.1186/s12879-017-2423-8

[23] Taei, M., Chadeganipour, M. and Mohammadi, R. (2019) An Alarming Rise of Non-albicans Candida Species and Uncommon Yeasts in the Clinical Samples; a Combination of Various Molecular Techniques for Identification of Etiologic Agents. BMC Research Notes, 12, Article No. 779.

https://doi.org/10.1186/s13104-019-4811-1

[24] Pemán, J. and Zaragoza, R. (2012) Combined Use of Nonculture-Based Lab Techniques in the Diagnosis and Management of Critically Ill Patients with Invasive Fungal Infections. Expert Review of Anti-infective Therapy, 10, 1321-1330. https://doi.org/10.1586/eri.12.128

[25] Pazos, C., Ponton, J. and Del Palacio, A. (2005) Contribution of ( $1 \rightarrow 3)$-Beta-D-Glucan Chromogenic Assay to Diagnosis and Therapeutic Monitoring of Invasive Aspergillosis in Neutropenic Adult Patients: A Comparison with Serial Screening for Circulating Galactomannan. Journal of Clinical Microbiology, 43, 299-305. https://doi.org/10.1128/JCM.43.1.299-305.2005

[26] Yera, H., Sendid, B., Francois, N., et al. (2001) Contribution of Serological Tests and Blood Culture to the Early Diagnosis of Systemic Candidiasi. European Journal of 
Clinical Microbiology \& Infectious Diseases, 20, 864-870.

https://doi.org/10.1007/s100960100629

[27] Li, F., Yu, X., Ye, L., et al. (2019) Clinical value of $(1,3)-\beta$-D-Glucan, Mannan, Antimannan IgG and IgM Antibodies in Diagnosis of Invasive Candidiasis. Medical Mycology, 57, 976-986. https://doi.org/10.1093/mmy/myy158

[28] De Pascale, G., Posteraro, B., D’Arrigo, S., et al. (2020) (1,3)- $\beta$-D-Glucan-Based Empirical Antifungal Interruption in Suspected Invasive Candidiasis: A Randomized Trial. Critical Care, 24, Article No. 550. https://doi.org/10.1186/s13054-020-03265-y

[29] Murri, R., Camici, M., Posteraro, B., et al. (2019) Performance Evaluation of the $(1,3)-\beta$-D-Glucan Detection Assay in Non-Intensive Care Unit Adult Patients. Infection and Drug Resistance, 12, 19-24. https://doi.org/10.2147/IDR.S181489 